\title{
LEGAL STATUS OF LAND RIGHTS OF THE MINING COMPANIES IN CENTRAL SULAWESI
}

\author{
Ikhsan Syafiuddin $^{\mathrm{a}}$, Agustina $^{\mathrm{b}}$, Budi Artha Pradana ${ }^{\mathrm{c}}$, Agus Lanini $^{\mathrm{d} *}$, Sulbadana $^{\mathrm{e}}$, Lembang \\ Palipadang ${ }^{\mathrm{f}}$ \\ Affiliation abcdef Universitas Tadulako \\ Corresponding author: aguslanini@untad.ac.id
}

\begin{abstract}
This study aims to describe and analyze the legal status of mineral mining companies' land in Central Sulawesi. Secondly, it seeks to explore and find alternative concepts in land use adopted by the community in the mining area and its surroundings. To achieve this goal, it will use a sociological/socio-legal research method. To obtain some data, document studies are carried out by searching for legal materials, primary, secondary and tertiary. Then field data collection was carried out in the form of observations, in-depth interviews, and participatory discussions (PRA). The phenomenon of problematic mineral mining occurs in almost every region in Indonesia, including Central Sulawesi. These facts show the importance of this research to be carried out in Central Sulawesi. The mining business is carried out after obtaining a permit from the government. Before the agreement with the party that has land rights, the government has first issued a mining business permit (in the future abbreviated as IUP). The IUP is given a settlement with the party, which has land rights to obtain approval. Land rights are fundamental in this regard, so the author believes that in granting mining business permits, comprehensive and effective consultation and deliberation first need to be carried out, involving communities directly affected by mining business activities so that land rights are guaranteed optimal.
\end{abstract}

Keywords: legal status; land; mining company.

\section{INTRODUCTION}

The Government of Indonesia encourages increased exploration and development of mineral resources within the territory of the Republic of Indonesia. If found in commercially viable quantities of minerals or ore deposits, the government will operate the mining business activities or provide opportunities for other parties.

Since 1967 (since the start of the New Order government), foreign investment has changed. The New Order government saw foreign investment as a way to accelerate economic growth. This policy can be seen with the issuance of the Foreign Investment Law no. 1 of 1967, which one of the articles provides a way for foreign investors to enter the mining sector (Article 8 of Law No. 11 of 1967). Not long after, Law no. 11 of 1967 concerning mining, which further paved the way for foreign investment in the mineral sector (Suripatty, 2009).

The implication of the two policies is the start of a contract system in mineral exploitation. The contract system results in the Indonesian State and the Company being on equal footing (become parties to the contract). In a position like this, the state has lost the administrative power to regulate mining companies operating in Indonesia.

Along with enacting Law no. 4 of 2009 concerning Mineral and Coal Mining, it must convert all forms of work contracts into mining business permits (IUP) (Vincent Fabian Thomas, 2019). This provision authorizes local governments to grant mining permits to applicant companies. This authority is strengthened in Law 22 of 2009 concerning Regional Government. Although then the central government has made changes/transfers of control from the district/city to the provincial government through Law No. 23 of 2014 concerning Regional Government (Putri \& W, 2015), (UURI/23/2014, 2014). 
The implications of the two laws raise the issue of overlapping concession tenure. It is caused by the actions of local governments that use their authority to issue mining permits without paying attention to procedures and field conditions that are different from the existing administrative map. So overlapping mining permits arise, both among permit holders and the community as plantation/location owners.

The reality up until now is that the people around the mining area have taken their land away from the company and have experienced the destruction of their livelihoods. It is caused by the lack of adequate protection from the government, which is caused by the inability of the government to protect the rights of the people living around the mining sites.

\section{LITERATURE REVIEW}

3.

As the holder of many other life resources, land has been fought over since the colonial era. In the current reform era, there is no change in public practice and policy on extractive production systems based on extensive land tenure, which conflicts with nature conservation and the livelihoods of the poor. The authorities invited the big capitalists to invest, even though it was not entirely successful (Lesta Trimiska, Wiryono, 2018), (Simarmata, 2012).

Meanwhile, during this reformation period, the appearance of residents increasingly faced parties who wanted to take natural resources by limiting residents' access. Violence and manipulation are still being used against these local people. Furthermore, the regulation of the land and natural resources and the accompanying institutions have not moved from the dualism between state and customary law, as happened in the colonial period. More than dualism, in practice, what happens is pluralism of regulatory practice. The chronic disease that continues to occur is sectoral government agencies, supported by various applicable laws (Mamase, 2013).

Then, the decentralization plan, which is intended to transfer several authorities from the central government to local governments, is not accompanied by arrangements regarding land and natural resource control. (Mohammad, 2017). In addition, the government is considered unable to realize the people's needs for certainty in land tenure and natural resources (Putri \& W, 2015).

The concept of a state based on the law was initiated by Plato in Nomoi's book, as did Emanuel Kant, who formally presented the rule of law principles; Julius Stahl, who proposed a substantive rule of law. And Dicey explained the concept of a rule of law state. (Krygier, 2018).

Indonesia is a state of law. In the concept of a state of law, it is idealized that what must be made commander in the dynamics of state life is law, not politics or economics. It built the rule of law by developing the legal instrument itself as a functional and just system. Land/mining arrangements are made as a superstructure and infrastructure of political, economic, and social institutions that are orderly and orderly.

The rule of law theory combines the concepts of state law and a welfare state. The state is obliged to protect its citizens as stated in Article 27 paragraph (l) of the 1945 Constitution (UUDNRI 1945, 1945). The protection given to legal subjects is in both preventive and repressive tools, both verbal and written. The concept of legal protection for the owner of the right to an object/land has been known for a long time; even the property right is a material right inherent in the object. (UURI/5/1960, 1960). So that it can defend it against anyone who will take it unlawfully (Friedman, 2006).

\section{RESEARCH METHOD}

This research is socio-legal research, namely research directly in the field supported by laws and related books. This research reveals the direction that lives in a society in their daily life (law in action). (Simarmata, 2006). Likewise, public perceptions and attitudes towards the relevant laws and regulations.

\section{RESULTS AND DISCUSSION}

\section{Status of Land Rights That Mining Companies Granted Rights}

Article 33 paragraph (3) of the Constitution of the Republic of Indonesia essentially stipulates that the state has the authority (right) to control its entire territory, which embodies in it a reference to regulate 
legal relations between people and land. Handling legal concerns in the understanding here is the state's decision to give land rights to its citizens, but there is also the authority to take over (revoke) these private rights.

The authority of the state in Article 33 paragraph (3) of the 1945 Constitution, when linked to Article 2 paragraph (2) of the BAL, gives the state the power to regulate and administer the allocation, use, supply, and maintenance of the earth, water, and space; Determine and regulate legal relations between people and the world, water and space; Determine and regulate legal relations between people and legal actions concerning the earth, water, and space.

One form of state authority in managing natural resources is granting permits by the state to mining companies. It is as mandated by Law Number 4 of 2009 concerning Mineral and Coal (Minerva), which is authorized to issue mining business permits is the central government in this case, the Ministry of Energy and Mineral Resources, the provincial government is the governor, and the district/city, in this case, is the regent/ mayor following his authority. It means that mining business activities can only be carried out after obtaining a permit from the government following its jurisdiction. In connection with granting a mining business permit, it will involve land that has land rights.

Talking about land rights, Urip Santoso argues that land rights give authority to the holder of the right to use and take advantage of the land they are entitled to (Gunanegara, 2008). In connection with this, Article 4 paragraph (2) of Law Number 5 of 1960 concerning Basic Agrarian Regulations (UUPA) stipulates that "The land rights referred to in paragraph 1 of this article authorize the use of the land in question; likewise, the body of the earth and water and the space above it is only needed for interests directly related to the use of the land within limits according to this law and higher legal regulations. (Boedi Harsono, 2008).

In this regard, land rights concerning granting mining business licenses are not necessarily used for granted because there is an authority protected by law over land rights. It is realized that the law guarantees every land right. Therefore, Article 134 paragraph (3) of Law No. 4 of 2009 stipulates that mining business activities are carried out after obtaining a permit from the government.

However, it is not clearly stated whether the agreement with the owner of the land rights takes precedence or the mining business permit takes precedence. However, it can be seen indirectly where in Article 134 it is stated that before the agreement with the party who has land rights, the government has first issued a mining business permit (in the future abbreviated as IUP) after the IUP is published then a settlement with the party who has land rights is used. Get approval.

On the other hand, the land is part of natural resources that support the survival of humankind. Human needs for land cover various things. The land is for agriculture (rice fields and plantations), residential areas, land for multiple types of industrial activities, and different fields and other development sectors.

Besides being useful for development activities, the land is a means of manifesting needs in the social field. Through land, one can realize social interaction, which means solidarity with community units in their environment. The land is sometimes used to maintain the status quo of social values that are incarnated in institutionalizing attitudes and behavior in a particular community.

Even land is used as a tool to bridge the process of realizing social care attitudes between fellow citizens in specific communities.

In general, the existence of customary land is legally recognized, as evidenced by several legal reinforcements such as the Basic Agrarian Law, which recognizes customary law in the land sector. As mentioned in the explanation of the law, especially in number III sub (1), the contents of which include:

".......because the majority of the Indonesian people are subject to customary law, the new agrarian law will also be based on the provisions of the customary law, as the original law, which was perfected and adapted to the interests of the people in the country modern and about the International, and adapted to Indonesian socialism...."

The consequences of the above provisions require state administration officials to respect the law that lives in the community, especially in the land sector, as mandated by the Basic Agrarian Law above. However, mining business permit issues such as overlapping land, not having an NPWP (Nomor 
Pokok Wajib Pajak), and the problem of paying taxes. All potentially breaking the law. Mining business license chaos is caused by data that is not integrated.

Transparency International Indonesia (TII) released the research results on the vulnerability and risk of corruption in the granting of mining permits. The unclear mechanism for auctioning mining business license areas is one of the main points prone to corruption.

Other vulnerabilities are potential corruption due to the weak mining financial audit system, weak law enforcement, lack of transparency, and public access to information on IUPs. Coordination between government agencies is also vulnerable, and the regulatory framework is not yet robust in supporting mining governance.

Corruption and irregularities in granting IUPs occur mainly because local governments are not ready for decentralization, and the issuance of implementing regulations for the 2009 Minerva Law has been slow. Local governments make implementing rules according to their respective versions.

After the 2009 Mining Law came into effect, the local government there were still exploration IUPs granted without an auction. Corruption in the issuance of permits can also occur when a company has more than one IUP but does not carry out any activities or even misuses the IUP for other activities such as logging.

Deviations in mining permit regulations are increasingly due to the desire of regional governments to pursue regional revenue targets, and there are political contestants in regional elections. Companies or mining business permits become a source of funds for candidates for regional heads.

Local governments grant many overlapping permits. These permits mostly overlap with Mining Business Permits (IUP). It is usually due to the overlapping authority between the central government and local governments.

Mining permits that are located above forest areas, community fields/gardens, and even settlements occur in the province of Central Sulawesi. The local government issues mining Business Permits. However, forest utilization permits remain with the central government, especially in areas where the population is still sparse; local governments can quickly issue permits even though they are contrary to statutory provisions. For example, there are still rights over the location that it gave a receipt. Apart from the tightening of permits by the government, the issue of overlapping land rights status or mining business permits overriding community rights must be seen as a legal issue.

Meanwhile, according to data from the Ministry of Finance for Non-Tax State Revenue (PNBP), mineral and coal mining in 2011 reached Rp 6.37 trillion, an increase from 2011. 2014 to Rp 19.3 trillion. Data for 2015 is the realization of revenues up to semester 1 with a value of Rp11.38 trillion. In 2016, PNBP revenue from this sector reached Rp. 15.76 trillion. In the first semester of 2017, IDR 10.49 trillion, or around 59.1 percent of the 2017 APBN target of IDR 17.73 trillion.

\section{The Attitude of Land Owners Towards The Awakening of Mining Company That Affect Their Land}

Humans come from the land and live from and on the land. The relationship between land and humans is very close. Human survival depends on the soil and vice versa. The relationship between land and humans is very different, depending on the needs, understanding, or presence of the land among humans (Moh. Soerjani, 1987). it shows that land is an essential natural resource in human life, which is currently a severe problem in Indonesia. One of them is related to the management of natural mining resources directly related to land rights.

In this regard, the management of mining business permits is realized that it will involve private lands. The Minerva Law in Articles 134 to 138 of the Minerva Law has determined the status of the land to be used by the IUP holder to carry out its activities. Those provisions are presented as follows (H. Salim, 2012):

a. The right to the mining business permit area does not include land rights. It means that the lands used by IUP holders to carry out their business activities are only temporary.

b. It cannot carry out mining business activities in places prohibited from carrying out mining business activities by the provisions of laws and regulations. There are exceptions to this provision. It means that IUP holders can carry out mining business activities after obtaining permits from government agencies following rules and regulations. 
c. The holder of an exploration IUP can only carry out its activities after obtaining approval from the holder of land rights.

d. The IUP holder, before it is required to settle the land rights with the land rights holders by the provisions of the legislation.

e. Settlement of land rights can be carried out in stages according to the needs of the land by the IUP holder.

f. IUP holders who have carried out the settlement of land parcels may be granted land rights by the provisions of laws and regulations.

It shows that the settlement of land rights is significant. It is not explicitly stated in Articles

134 to 138 of the Minerva Law concerning agreements with land rights holders that take precedence or whether the granting of permits by the government is preceded. If it is studied in depth that the government grants permits first, then an agreement is made with land rights holders. It gives the impression that what is assessed here is granting permits that are more dominant. The protection of land rights holders is indirectly ignored. Land rights, as explained above, are the authority attached to the holders of land rights. The power connected to the holder of land rights is normatively protected by law. Property rights, according to Hegel, are a characteristic of positive direction. The term right is a claim or claim, and interest is a claim that is protected by law.

According to Sudikno Mertokusumo, rights are protected by law, while interests are individual or group demands expected to be fulfilled. (Sudikno Mertokusumo, 2012). There must be a balance between personal interests and group interests, and when there is no balance between the two, there will be conflict. Therefore, humans need to protect their interests (Sudikno Mertokusumo, 2011).

The existence of land rights and the granting of mining business permits is an ongoing problem, so it takes a sincere and firm intention to resolve. The business license that has been received by the mining business license holder, in reality, is the granting of absolute authority; this happens in practice so that people who have land rights are ignored on the argument that they have obtained a permit. It did not reach an agreement. The refusal occurred; the state was present at that time through state tools such as the police, who later became the community's opponent to defend their rights.

They should realize that land use must be beneficial both for the welfare and happiness of those who own it and for the benefit of the community and the state. But the interests of society and individual attractions must balance each other so that in the end, the main goal will be achieved: prosperity, justice, and happiness for the people as a whole (Gunanerala et al., 2008). So all issues related to the management of mineral and coal mining must lead to the greatest prosperity of the people. The principle of the most excellent means of the people is a point that the state apparatus must carry out, the government (Nadang Sudrajat, 2013), so development is not justified to torture the people.The essence of natural resource management, especially mining management, is to create people's prosperity. As mandated by Article 33 paragraph (3) of the UUDNRI, in essence, the state appears as an authorized institution, not owns it. Authority in the mining sector should be divided into regulatory, administering, and supervising authorities (Adrian Sutedi, 2012) and make the best use of these natural resources for the prosperity of the people.The existence of land in a juridical sense is ownership rights over land. Mastery in a juridical sense is control based on fairness, which is protected by law in general, giving the right holder the authority to control the land being entitled to, for example, physically, the landowner uses or takes advantage of the land being allowed to, not handed over to other parties. (Urip Santoso, 2009). According to Efendi Perangin (1989), the contents of the right of tenure include obligations, certain powers, and specific prohibitions. The responsibilities, authorities, and bans are related to Article 6 of the UUPA, namely that land has a social function. It is based on General explanation II number 4 that any land rights that exist in a person cannot be justified, that it will use the land solely for his interests.

The use of land must be beneficial both for the welfare and happiness of those who own it and also for the benefit of society and the state. It is a measure of individual interests, and it must balance personal interests with each other.

It shows how important it is to respect and maintain harmony between rights and land in its implementation, so the government's granting of mining business permits must pay close attention to 
this. So that it can guarantee the principle of balancing in land use. The BAL also stipulates that it must maintain the land and possibly increase its fertility and prevent damage. The obligation to possess this land is borne by the owner or the holder of the rights concerned. It becomes the burden of every person, legal entity, or agency with a legal relationship with the land.

The mandate to maintain the land to prevent its damage in mining practice shows that there are so many environmental pollution problems and environmental destruction by the mining business permit holder. It is based on the results of research by the Ministry of the Environment in 2015 showing that 24.3 million hectares of forests throughout Indonesia are degraded. (https://nasional.tempo.co/read/news). About the direct destruction of the environment, the mandate of the UUPA has not been implemented optimally. In this regard, the government's granting mining business permits following its authority needs to be carefully and precisely scrutinized. Land rights are fundamental in this regard. In giving mining business permits, comprehensive and effective consultations and deliberation must be carried out first, involving communities directly affected by mining business activities, so land rights remain optimally guaranteed.

Considering that the quality of the problem is generally cross-sectoral and has many aspects and dimensions, including legal, economic, socio-cultural, political, and defense, and security dimensions. (Darwin Ginting, 2010), Therefore, according to Arie S. Hutagalung, for the development and control of land as a natural resource to be following populist-based development programs as mandated in Pancasila and the 1945 Constitution, it is necessary to organize land use that it cannot separate from the regulation, control, and ownership of land. . The existence of stipulations regarding the use of land rights for mining business activities is a legal provision which is formally juridical as a form of respect for land rights. According to some research results, in general, the level of community involvement is shallow. Instead of inviting residents whose areas will be used for Mining to discuss short and long-term plans, the government only conducts socialization. Or a meeting without paying attention to input and suggestions from the community concerned. It must protect the land as a productive asset of the people. Therefore, the people/communities who own land in contact with mining need to increase their knowledge to be aware of legal protection for landowners related to the determination of mining areas.

\section{CONCLUSION}

The community's attitude towards land/land control by the company generally considers it to be owned by the company because it has been acquired (purchased). The company also addresses it by installing boundary signs/fences and announcement boards about company rights. However, these rights are only temporary because they are not property rights. The mining business is carried out after obtaining a permit from the government. Before the agreement with the land rights party, the government has first issued a mining business permit (abbreviated as IUP). After the IUP is given, settle with the party, who has land rights, to obtain approval. If the parties agree, the status of the land rights will be released, and the company will then apply for the rights].

\section{REFERENCES}

Brockhaus, M., Obidzinski, K., Dermawan, A., Laumonier, Y., \& Luttrell, C. (2012). An overview of forest and land allocation policies in Indonesia: Is the current framework sufficient to meet the needs of REDD+? Forest Policy and Economics, 18, 30-37. https://doi.org/10.1016/j.forpol.2011.09.004

Friedman, L. M. (2006). The Law and Society Movement. Stanford Law Review, 38(3), 763-780. https://doi.org/10.2307/1228563

Krygier, M. (2018). Why the rule of law matters. Jurisprudence. https://doi.org/10.1080/20403313.2017.1331633

Lesta Trimiska, Wiryono, H. S. (2018). Kajian Penambangan Emas Tanpa Izin (PETI) di Kecamatan Lebong Utara Kabupaten Lebong. Naturalis: Jurnal Penelitian Pengelolaan Sumber Daya Alam Dan Lingkungan, 7(1), 9. https://doi.org/10.11164/jjsps.16.4_704_3

Mamase, N. A. B. D. (2013). Penegakan Hukum Terhadap Izin Usaha Pertambangam di Kabupaten Morowali Provinsi Sulawesi Tengah. Universitas Ilslam Indonesia. 
Mohammad, Y. (2017, December 7). Mengurai Kusut Izin Pertambangan Di indonesia. Batagar, pp. $16-17$.

Putri, R. Z., \& W, L. T. A. L. (2015). Kajian Politik Hukum Tentang Perubahan Kewenangan Pemberian Izin Usaha Pertambangan Mineral dan Batubara. Jurnal Law Reform, 11(2), 199-206.

Simarmata, R. (2006). Socio Legal Studies dan Gerakan Pembaharuan Hukum. Digest Law, Society \& Development, 1(12), 1-10.

Simarmata, R. (2012). Indonesian law and reality in the Delta : a socio-legal inquiry into laws, local bureaucrats and natural resources management in the Mahakam Delta, East Kalimantan. Leiden University dissertation. Leiden. https://doi.org/10.1017/CBO9781107415324.004

Suripatty, V. I. (2009). Paradigma Baru Hukum Pertambangan Indonesia, Mengganti Sistem Kontrak Karya Dalam Kegi Pertambangan Mineral. Indonesia.

AUDI 1945. The 1945 Constitution of the Republic of Indonesia (1945). Indonesia: Setneg RI.

UURI/23/2014. UURI No 23 Tahun 2014 Tentang Pemerintahan Daerah, Pub. L. No. 23 (2014). Indonesia.

UURI/5/1960. UURI No. 5 Tahun 1960 Tentang Peraturan Dasar Pokok-Pokok Agraria Republik Indonesia, Pub. L. No. 5 (1960). Indonesia.

Vincent Fabian Thomas. (2019, October 2). Bahaya Revisi Undang Undang Pertambangan Minerba. Jatam. 